Original Research

\title{
The Role of Family as A Caregiver in Caring for Family Members that are Suffering from Pulmonary Tuberculosis
}

\section{Beti Kristinawati ${ }^{1}$, Annisa Muryadewi ${ }^{1}$, and Ana Dwi Irianti ${ }^{2}$}

${ }^{1}$ School of Nursing, Universitas Muhammadiyah Surakarta, Solo, Indonesia

${ }^{2}$ Center Public Hospital, Klaten, Indonesia

\begin{abstract}
Introduction: Families have an important role in the successful treatment of people with pulmonary tuberculosis. The purpose of this study was to obtain an overview of the role of the family as a caregiver in caring for family members suffering from pulmonary tuberculosis.

Methods: The phenomenological qualitative design was chosen to obtain indepth information by interviewing thirteen family members who cared for pulmonary tuberculosis patients determined through a purposive technique.

Results: The content of Collaizi's analysis produced five themes, namely: 1) Nonpharmacological therapy is given by the family to treat symptomatic pulmonary tuberculosis 2) Efforts to cut transmission was carried out by the family to prevent transmission of disease, 3) Nutrition support provided by families in treating patients, 4) Instrumental support given by families in caring for pulmonary tuberculosis patients, 5) Emotional support given by families in treating pulmonary tuberculosis sufferers.

Conclusion: The family provides physical and psychological care to support the successful treatment of pulmonary tuberculosis. A program is recommended to increase family knowledge in caring for family members suffering from pulmonary tuberculosis. Words are sorted alphabetically.
\end{abstract}

\section{ARTICLE HISTORY}

Received: Dec 26, 2019

Accepted: Dec 31, 2019

\section{KEYWORDS}

pulmonary tuberculosis; phenomenological; family; support; knowledge

\section{CONTACT}

Beti Kristinawati

\bk354@ums.ac.id

$\equiv$ School of Nursing, Universitas Muhammadiyah Surakarta, Solo, Indonesia

Cite this as: Kristinawati, B., Muryadewi, A., \& Irianti, A. D. (2019). The Role of Family as A Caregiver in Caring for Family Members that are Suffering from Pulmonary Tuberculosis. Jurnal Ners, 14(3si), 362-366. doi:http://dx.doi.org/10.20473/jn.v14i3(si).17214

\section{INTRODUCTION}

Tuberculosis is an infectious disease caused by Mycobacterium tuberculosis and usually attacks the lung organs or other organs of the body. Tuberculosis that attacks other parts of the body can be caused by incomplete treatment (Brunner \& Suddarth, 2013). Data from the World Health Organization / WHO, there was an increase in cases of pulmonary TB, which amounted to 6.3 million cases from 6.1 million cases in 2015. This number is equivalent to $61 \%$ of the estimated incidence of 10.4 million cases of pulmonary $\mathrm{TB}$, where $56 \%$ are in five countries, namely India, Indonesia, China, the Philippines, and Pakistan (World Health Organization, 2017).

The prevalence of TB in the World in 2015 was 10.4 million new cases of tuberculosis or 142 cases / 100,000 populations, with 480,000 cases of multidrug-resistance. Indonesia is a country with the second largest number of new cases in the world after India. $60 \%$ of new cases occur in 6 countries, namely India, Indonesia, China, Nigeria, Pakistan and South Africa (World Health Organization / WHO, 2016). Globally, in 2017, the TB mortality rate in the world is 16\% (World Health Organization, 2017). Data in Indonesia shows that deaths from tuberculosis are estimated at 1.4 million. This number increased with TB comorbidities. This number increased with TB comorbidities of 0.4 million in 2016 (KaulagekarNagarkar, Dhake, \& Jha, 2012).

The high incidence and mortality, due to tuberculosis, encourages the Indonesian state to improve the treatment and care of tuberculosis patients. Treatment of good TB patients can help speed healing (Friedman, MM, Bowden, VR, \& Jones, 2010). In the treatment of pulmonary tuberculosis, the role of the family is needed, especially in providing care and support. Family contributions to 
the treatment of tuberculosis can be in the form of support and care (Samal, 2017). Treatment is not only physical care but psychosocial treatment. Actions that can be taken by the family in caring for family members, for example by monitoring patients in taking medicine regularly, fulfilling nutritional needs, and increasing nutritional intake to increase the immune system of people with tuberculosis r(Indyah Rachmawati, S, \& Isabella, 2015). Care provided by the family can be in the form of providing motivation to fight the disease, not despairing, and not thinking negatively thought such as suicide or leaving home (Ministry of Health, 2017).

There is enough research about the role of families in caring for pulmonary tuberculosis patients, but the conclusions obtained from these studies are still not uniform, so researchers assume that exploration is still needed on the role of families as caregivers in treating pulmonary tuberculosis patients. The results of this study are expected to have the effect of increasing the ability of families as a caregiver in treating pulmonary tuberculosis patients. This study aimed to explore the role of families as caregivers in caring for family members who suffer from TB.

\section{MATERIALS AND METHODS}

\section{Design}

This study is a qualitative study with a phenomenological approach carried out in the Pajang Surakarta Health Center Work Area. Data was collected by interviewing participants who had family members suffering from pulmonary tuberculosis.

\section{Participants}

The number of participants in qualitative research is determined based on the focus or depth of information expected by the researcher. In this study, the number of participants was determined according to the saturation of data. Thirteen participants were included in this study. Participants involved in the study were selected by purposive sampling technique. Determination of participants based on predetermined criteria, namely; over eighteen years old, family as caregiver who treats family members with pulmonary tuberculosis, families with experience caring for tuberculosis sufferers for aminimum of six months and living in one house.

\section{Data Collection}

Participants who were selected and willing to participate in the study were given a questionnaire containing demographic data and followed by indepth interviews. Open-ended questions were used in interviews to explore family experiences in caring for family members suffering from pulmonary tuberculosis. Interviews were conducted face to face for 45-60 minutes in a place desired by the participants and agreed upon by the researchers. When conducting interviews, researchers used interview guidelines that contained research topics, and if any, the information presented by participants
Table 1 Interview outline

1. How is your experience while caring for family members who suffer from pulmonary tuberculosis

2. Please tell us about the actions that have been taken to prevent transmission of the disease while caring for family members suffering from pulmonary tuberculosis?

3. What is your role in treating pulmonary tuberculosis suffered by family members?

4. What are your efforts in meeting nutritional needs when caring for family members suffering from pulmonary tuberculosis?

5. Please tell me about the support that has been given to family members who suffer from pulmonary tuberculosis

needed to be explored more deeply, the researchers used probes. During the interview process, the researcher records a general description of the participant's nonverbal response into the note field. The researcher bracketing, intuiting, analyzing, and describing to obtain information that comes from truly natural participants. The interview guide used in this study is explained in table 1.

\section{Ethical Considerations}

This research was approved by the UniversitasMuhammadiyah Surakarta Committee, Faculty of Medicine. A number of ethical certificate 96/I/HREC/2019. Researchers protect and guarantee the confidentiality of participants involved in research by maintaining the confidentiality of the participant's identity. In addition, only certain data will be reported and published with permission from the participants. The results of the interviews and verbatim transcripts were only known by researchers and participants.

\section{Data Analysis}

The seven stages of the Colaizzi method (1978) are applied to analyze information obtained from interviews. This method was chosen because, at the end of the analysis, there is a final validation activity that must be carried out by the researcher to ensure trustworthiness. The stages of data analysis use the Colaizzi method which includes reading repeatedly verbatim transcripts that contain descriptions of participants about the phenomenon being studied, identifying specific statements conveyed by the participants and then making them as keywords. This specific statement will be given a code(coding) by giving colour to specific words. The next stage is to formulate the meaning of each specific statement and proceed with grouping the meanings that have been made into categories, identifying the relationships of each category and grouping them into themes. After the theme is formed, the researcher carries out final validation on the participant, and if new data is found at the end of the validation, it will be combined with a complete description.

The validity of the data from this research is maintained.The validity of the data from this research 
Table 2. Demographic characteristic of the participants

\begin{tabular}{lcc}
\hline \multicolumn{1}{c}{ Characteristics } & Number & $\%$ \\
\hline Gender & 3 & 23,1 \\
$\quad$ Male & 10 & 76,9 \\
$\quad$ Female & 4 & 30,8 \\
Age & 9 & 69,2 \\
24-40 year & & 46,2 \\
41-57 year & 6 & 46,2 \\
\hline Job Housewife & 6 & 7,7 \\
Private sector & 1 & 23,1 \\
Civil Servant & & 7,7 \\
\hline Education Level & 3 & 53,8 \\
Primary School & 1 & 15,4 \\
Junior High School & 7 & 61,5 \\
High School & 2 & 7,7 \\
Bachelor & & 15,4 \\
\hline Treatment period & 8 & 15,4 \\
6 month & 1 & 2 \\
8month & 2 & \\
9 month & 2 & \\
10 month & & \\
\hline
\end{tabular}

Table 3. Analysis of the content of the role of families as care giver in caring for family members who have pulmonary tuberculosis

\begin{tabular}{|c|c|c|}
\hline Coding & Category & Theme \\
\hline $\begin{array}{l}\text { Nonpharmacological therapy is } \\
\text { given by family }\end{array}$ & Nonpharmacological therapy & $\begin{array}{l}\text { Nonpharmacological therapy is given by the } \\
\text { family to treat symptomatic pulmonary } \\
\text { tuberculosis }\end{array}$ \\
\hline \multicolumn{3}{|l|}{$\begin{array}{l}\text { Dyspnea management } \\
\text { Complementary therapy }\end{array}$} \\
\hline $\begin{array}{l}\text { Prevent the risk of transmission } \\
\text { tuberculosis }\end{array}$ & $\begin{array}{l}\text { Family strategy in preventing TB } \\
\text { transmission }\end{array}$ & $\begin{array}{l}\text { Efforts to cut transmission was carried out } \\
\text { by the family to prevent transmission of } \\
\text { disease }\end{array}$ \\
\hline Giving nutrition food & $\begin{array}{l}\text { Fulfilment of nutrition intake by the } \\
\text { family }\end{array}$ & $\begin{array}{l}\text { Nutrition support provided by families in } \\
\text { treating patients }\end{array}$ \\
\hline
\end{tabular}

is maintained by researchers by applying the principles of credibility, transferability, dependability and confirmability. The degree of credibility is attempted by including verbatim quotes from the results of interviews. Second, the possibility of research results can be applied to other groups with different conditions (transferability) conducted by researchers by providing descriptions of data that support the research process. Third, data stability (dependability) is maintained by auditing the research process by means ofan audit trail of listening to the results of multiple interviews, checking verbatim transcripts made and examining the results of the interpretation of the data obtained. Fourth, confirmability is carried out by researchers by means of researchers explaining conclusions and interpreting the data obtained to reflect the family plan as caregiver in treating tuberculosis sufferers.

\section{RESULTS}

Demographic data on the characteristics of participants are described in table 2. Based on the verbatim analysis, a detailed description of the family performance as a caregiver who cared for families suffering from pulmonary tuberculosis was obtained. The Categories, abstracted to themes that emerged from the analysis process is shown in table 3. The table above shows that the results of the analysis based on the Colaizzi data analysis stage formed six categories which have been drawn down into five broad themes.

\section{DISCUSSION}

\section{Theme: Nonpharmacological therapy is given by the family to treat symptomatic pulmonary tuberculosis}

TB disease suffered by patients often causes symptoms that cause sufferers to feel uncomfortable. The family stated in handling the initial symptoms by administering nonpharmacological therapy. Families interpret nonpharmacological therapy as a first aid measure in reducing symptomatic arising. Symptomatic arises in the form of shortness of breath and coughing. Families take non-pharmacological 
actions in the form of giving eucalyptus oil. Here are some participant statements:

"Coughing, then I will use oil to make it warm... and I use massage oil to reduce it..." (P11)

"It's covered with oil... I use eucalyptus oil so that the patient feels warm..." (P12)

Family is the leading health care unit in improving health status. And having the function of providing health care aims to maintain the health condition of family members. The family also performs its role in preventing health problems and caring for sick family members (Suprajitno, 2012). Health care carried out by the family is influenced by family actions or behaviour towards stimuli related to illness and disease (Friedman, MM, Bowden, VR, \& Jones, 2010). Family efforts to reduce symptoms of shortness of breath in TB patients can use pharmacological therapy and non-pharmacological therapy. The results showed the effect of aromatherapy on mint leaves with simple inhalation on decreasing shortness of breath in pulmonary tuberculosis patients. Mint leaves containing essential menthol can loosen breathing (Shrivastava, Shrivastava, \& Ramasamy, 2015).

\subsection{Theme: Efforts to cut transmission was carried out by the family to prevent transmission of disease}

The attempt to cut the transmission of TB transmission is meant that participants take actions that can prevent the risk of TB transmission. Prevention of TB transmission by families in accordance with the recommendations of health workers. Actions carried out by the family, such as using a mask, not throwing phlegm anywhere and separating the eating equipment and drinking the patient. besides, family business in preventing TB transmission by providing an understanding of tuberculosis sufferers. The following is a quote from the participant's expression:

"Next..ee... prepare a mask... Father must be selfaware if he is sick. I am afraid the disease will be contagious, so the Father is given an understanding of the importance of using his mask "(P4)

"The spit is placed in a closed place... a special place for saliva and given Karbol, so that the germs die..." (P5)

\section{"The glass used is separated... to prevent transmission" (P4)}

Prevention is an effort to protect patients from health threats. Prevention efforts are carried out so that everyone is spared from contracting a disease and preventing the spread of disease (Febriansyah, 2017). According to Ali in 2010, prevention of transmission of diseases carried out by families was included in the form of duties or family roles. One of the tasks of the family is to care for sick family members and prevent transmission to healthy family members (Ali, 2010)

\subsection{Theme: Nutrition support provided by families in treating patients}

Participants interpret nutritious food as a family effort to meet the nutritional needs of tuberculosis patients. The family said that providing nutrition will help the healing process of family members who suffer from tuberculosis at home. The family provides nutrients in the form of protein (milk) and fruits during the treatment process. Milk is given in sufficient quantities with frequent frequency while fruits are given approximately one to three times a week. The following is a quote from the participant

"Almost everyday milk is made... goat milk" (P3)

"I give bananas, grapes... Essentially everyday fruit is provided "( $\mathrm{P} 12)$

Adequate nutrition can help increase endurance. Endurance can decrease when poor nutrition conditions so that the ability to defend themselves against infection decreases (Gupta, Gupta, Atreja, Verma, \& Vishvkarma, 2009). Other research shows that $51.3 \%$ of tuberculosis sufferers have poor nutritional status. Poor nutritional status increases the risk of tuberculosis (Arsunan, A. A., Wahiduddin, \& Ansar, 2013).

\subsection{Theme: Informational support given by families in caring for pulmonary tuberculosis patients}

Participants interpret informational support as family actions in supporting or supporting treatment for family members suffering from tuberculosis. Information provided by the family is in the form of reminding sick members to take medicine and accompanying control to health services. The following is a quote from the participant's statement:

"I always remind you to... the medication should not forget, later... repeat the treatment" (P3)

"So I also reminded myself to take medicine... for six months I reminded myself to recover" (P11)

The family is the first person who knows about the condition of the patient and the person who is closest and communicates every day with the patient. Families have an important role in the treatment process of patients. The family can be used as a PMO (Superintendent of Swallowing Drugs) because the family is trusted, known, and approved by health workers and sufferers as well as staying close or one house with patients (Ministry of Health, 2017).

\subsection{Theme: Families give emotional support in treating pulmonary tuberculosis sufferers}


Emotional support means that the family as the closest person to the patient gives motivation to family members who are sick during the treatment process. Tuberculosis sufferers need considerable time for treatment, so, patients need the motivation to minimise the negative response to treatment. The following is the expression of the participant's statement:

"In my daily life, I support patients... so that they can have the spirit of treating" (P3)

"Eee... I really motivate him... support him" (P12)

Motivation is a basic impulse that moves and directs someone to act to achieve certain goals. The results of encouragement and movement are manifested in the form of behaviour. Own behaviour is formed through a certain process and takes place in the interaction of a person with his environment (Donsu, 2017). Motivation is interpreted as a force or factor contained in someone who raises and moves his behaviour.

\section{CONCLUSION}

The role of the family as caregiver in caring for family members is illustrated in five themes, namely; 1) Family experience in preventing disease transmission while caring for family members suffering from tuberculosis, which is accommodated by the theme of efforts to cut transmission carried out by families to prevent disease, 2) family role in treating tuberculosis sufferers accommodated by the theme of nonpharmacological therapy given by families to overcome symptomatic pulmonary tuberculosis The family's role in fulfilling nutritional needs in caring for family members sufferingfrom tuberculosis is accommodated by the theme Nutrition support provided by families treating patients, 4) social support provided when caring for family members suffering from tuberculosis is accommodated by the theme of informational support given to families in caring for tuberculosis patients and the theme of emotional support is given by the family in caring for tuberculosis patients.

\section{REFERENCES}

Ali, Z. (2010). Introduction to Family Nursing. Jakarta: EGC.

Arsunan, A. A., Wahiduddin, \& Ansar, J. (2013).
Overview of Nutritional Substance and Nutritional Status of Patients with Pulmonary TB in Makassar City. Hasanuddin.

Brunner \& Suddarth. (2013). Textbook for MedicalSurgical Nursing (1st ed.). Jakarta: EGC.

Donsu, J. D. T. (2017). Nursing Psychology Aspects of Psychology Basic Concepts Psychology Theory of Human Behavior. Yogyakarta: New Library Press.

Febriansyah, R. (2017). hubungan Tingkat Pengetahuan Keluarga dengan Upaya Pencegahan Penularan Tuberkulosis Paru pada Keluarga di Wilayah Kerja Puskesmas Sukoharjo. Universitas Muhammadiyah Surakarta.

Friedman, MM, Bowden, VR, \& Jones, E. (2010). Family nursing textbook: Research, theory, and practice. Jakarta: EGC.

Gupta, K., Gupta, R., Atreja, A., Verma, M., \& Vishvkarma, S. (2009). Tuberculosis and nutrition. Lung India. https://doi.org/10.4103/0970-2113.45198

Indyah Rachmawati, N., S, S., \& Isabella, C. (2015). Kebutuhan Psikososial Keluarga yang Mempunyai Anggota Keluarga MenderitaTB Paru. Jurnal Keperawatan Padjadjaran, v3(n1), 25-32. https://doi.org/10.24198/jkp.v3n1.4

Kaulagekar-Nagarkar, A., Dhake, D., \& Jha, P. (2012). Perspective of tuberculosis patients on family support and care in rural Maharashtra. Indian Journal of Tuberculosis.

Ministry of Health. (2017). Indonesian Health Profile 2016. Jakarta: Ministry of Health of the Republic of Indonesia.

Samal, J. (2017). Family perspectives in the care and support of tuberculosis patients: An Indian context. The Journal of Association of Chest Physicians. https://doi.org/10.4103/23208775.202899

Shrivastava, S., Shrivastava, P., \& Ramasamy, J. (2015). Scope of family in public health: An epidemiologist's perspective. Muller Journal of Medical Sciences and Research, 6(1), 101. https://doi.org/10.4103/0975-9727.146480

Suprajitno. (2012). Family Nursing Care: Application in Practice. Jakarta: EGC.

World Health Organization. (2017). Global Tuberculosis Report. France. 